\title{
Recent trends in airborne pollen for tree species in Galicia, NW Spain
}

\author{
F. J. Rodríguez-Rajo ${ }^{1, *}$, M. J. Aira ${ }^{2}$, M. Fernández-González ${ }^{1}$, C. Seijo ${ }^{1}$, V. Jato ${ }^{1}$ \\ ${ }^{1}$ Department of Plant Biology and Soil Sciences, Sciences Faculty, Polytechnic Building, Campus As Lagoas, \\ University of Vigo, 32004 Ourense, Spain \\ ${ }^{2}$ Department of Botany, Faculty of Pharmacy, Campus Sur, University of Santiago de Compostela, \\ Santiago de Compostela 15706, Spain
}

\begin{abstract}
The global climate change recorded over recent years may prompt changes in phenological events. The present study sought to analyse the varying impact of changes in weather conditions at different times of the year on woody-plant flowering, by analysing recent trends in airborne count for 3 pollen types abundant in Galicia belonging to the Fagales order: Alnus, which flowers in early winter; Betula, in early spring; and Castanea, in early summer. Pollen sampling was performed using Hirst-type volumetric traps in Ourense, Santiago, Vigo and Lugo; data were subjected to regression models, applied using the SPSS 17.0 statistical software package. The atmospheric pollen season started later in Lugo; the lower winter minimum temperatures in Lugo compared to the other 3 cities over the study period would explain the higher chilling accumulation recorded. The trend towards increasing temperatures was more marked in the south of Galicia (Vigo and Ourense) than in more northern cities. Mainly, maximum temperatures in September or October displayed an increasing trend at Ourense, Vigo and Lugo, while summer temperatures showed significant increases in Ourense. The temperature increase detected, especially during spring and summer, could account for the slight trend towards an earlier pollen season onset in all 4 cities, and for the advance of the Castanea pollen-season end date observed in Ourense.
\end{abstract}

KEY WORDS: Aerobiology - Phenological trends - Flowering - Chilling - Heat requirements · Seasonal trends Resale or republication not permitted without written consent of the publisher

\section{INTRODUCTION}

Airborne pollen data have been used in recent years as phenological indicators of the timing of flowering over a wide area (Jato et al. 2007), and to evaluate delays or advances in the onset of pollination in major wind-pollinated species. Although airborne pollen counts are strongly influenced by the vegetation surrounding the pollen trap, year-on-year variations may be attributed to a wide range of parameters, particularly weather conditions both before and during pollination.

In temperate climates, many species have evolved mechanisms to protect cells from the risk of frost during adverse weather conditions in the period prior to flowering. After summer, the growth of woody plants slows down and they enter a physiological state known as la- tency, in which vegetative activity diminishes or ceases. This state begins when buds are exposed to cool temperatures over a certain period of time, during which plants complete their 'chilling requirement', the minimum period of cold weather after which a plant will flower. Thereafter, buds remain inactive as a result of unfavourable environmental conditions (quiescence or dormancy), but their exposure to increasing temperatures allows them to reach the heat requirement ('forcing units') that forces bud break and flowering. Both the chilling and heat requirements, as well as a predetermined threshold temperature, are specific to every species.

According to all climate models assessed by the IPCC, increases in global mean surface temperatures are likely to continue throughout the 21st century (IPCC 2007). The rate of increase varies depending 
on the geographical area. Temperature trends are expected to display regional differences, and therefore their influence on phenological events is unlikely to be uniform. Changes in rainfall patterns are less marked than temperature variations, mainly due to the complexity of spatial and temporal rainfall distribution (Meehl et al. 2007). Although model simulations suggest a global increase in mean rainfall, a substantial decline (of up to $20 \%$ ) is expected in the Mediterranean region in the course of the present century. Seasonal rainfall patterns are unlikely to be uniform all over the Iberian Peninsula, and the decrease in rainfall will be particularly significant in summer and spring (del Rio 2005).

Changes in climate conditions affecting the atmospheric pollen season (APS) are likely to be more evident in early-spring tree species. Several areas in Europe have reported earlier flowering onset in species such as alder, hazel, birch or oak (Emberlin et al. 2002, García-Mozo et al. 2006, Frei \& Gassner 2008), the advance proving even more marked where the weather has become warmer. However, the advance has so far proved less evident for late-spring species (Emberlin et al. 2002). Moreover, a trend towards higher daily mean pollen counts has also been reported for birch (Frei \& Gassner 2008).

In Galicia (Spain), abrupt variations in temperature and rainfall distribution over the period since 1972 have been highlighted in recent studies (Cruz et al. 2009). Changes appear to be more pronounced for maximum temperature (mainly in spring and summer), and include a tendency towards an increase in rainfall in autumn and a decrease in February (Cruz et al. 2009). Although specific studies have addressed recent trends in APS in Galicia (Jato et al. 2009, Recio et al. 2009), the present study is the first comparative study of species flowering at different times of the year. The present study sought to analyse the varying impact of changes in weather conditions at different times of the year on phenological events, by analysing recent trends in airborne count for 3 allergenic pollen types abundant in Galicia belonging to the Fagales order: Alnus, which flowers in early winter; Betula, in early spring; and Castanea, in early summer. In NW Spain, between 13 and $60 \%$ of hay fever sufferers are allergic to Betula pollen, between 9 and $20 \%$ to Alnus, while a lower percentage of $2 \%$ of skin sensitisation to Castanea pollen is detected among pollinosis sufferers (Belmonte et al. 1998). Symptoms frequently occur over long periods due to the overlapping of flowering in the different species and the related reactivity between the pollen of Alnus, Betula, Castanea, Quercus and Poaceae (Ickovic \& Thibaudon 1991). The correlation between detected variations in pollen counts and a number of environmental-and especially weather-relatedfactors was analysed at 4 sites in Galicia (NW Spain).

\section{MATERIALS AND METHODS}

\subsection{Study area}

The 4 cities studied are located in Galicia (NW Iberian peninsula) (Fig. 1). The boundary between the Eurosiberian and Mediterranean regions splits Galicia into 2 territories: Lugo, Santiago and Vigo are located in the Eurosiberian, and Ourense in the Mediterranean region (Rivas-Martinez \& Rivas-Saenz 2010). The general Galician climate is influenced by the Atlantic Ocean, but a number of climatic differences between the 4 cities were detected. Ourense shows a stronger Mediterranean influence, with greater oscillations in temperature (summer vs. winter and day vs. night) and lower annual rainfall than the other 3 cities (Table 1).

\subsection{Pollen types}

Data of daily mean pollen concentrations were gathered for 3 arboreal species flowering at different times: Alnus, Betula and Castanea. A. glutinosa (L.) Gaertner is the only Alnus airborne pollen source in the area. This is a autochthonous tree and a dominant species in

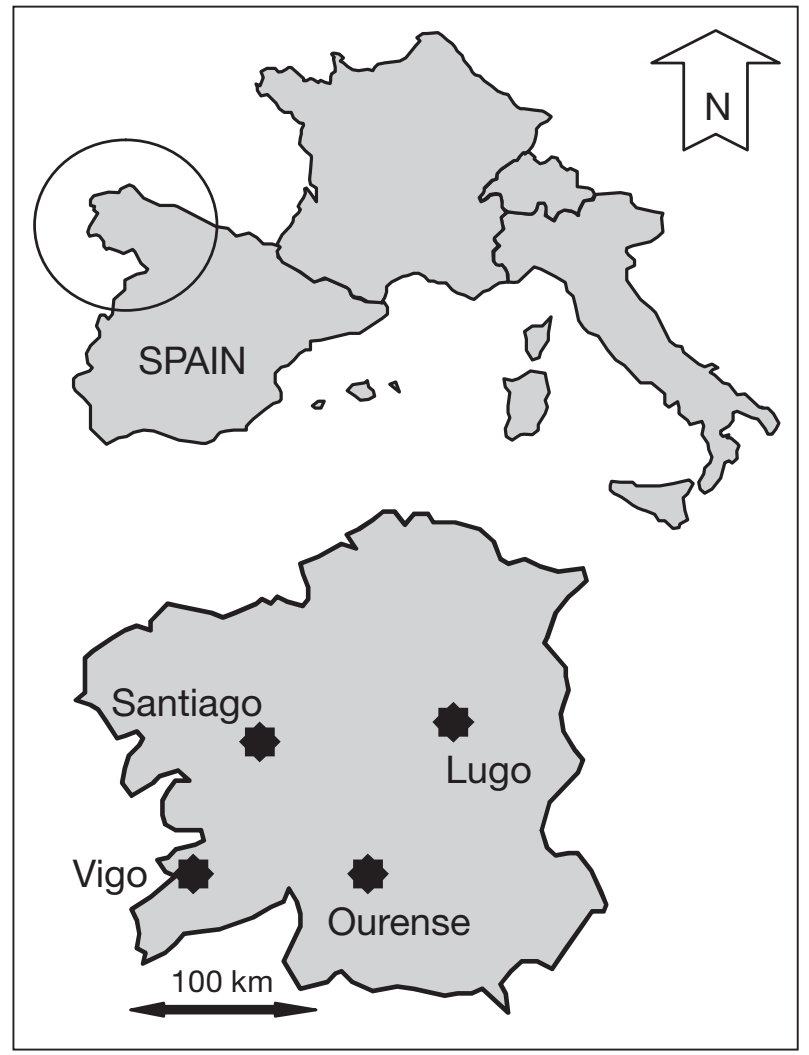

Fig. 1. Location of Vigo, Ourense, Santiago and Lugo in western Europe 
Table 1. Biogeographic and climatic characterisation of the areas studied. Eurosiberian: Eurosiberian region, Cántabro-Atlántica province, Galaico-Portugués sector; Mediterranean: Mediterranean region, Carpetano-Iberico-Leonesa province, OrensanoSanabriense sector. Climate characteristics are annual mean data

\begin{tabular}{|llccccc|}
\hline City & $\begin{array}{l}\text { Biogeography } \\
\text { (subsector) }\end{array}$ & $\begin{array}{c}\text { Temperature } \\
\left({ }^{\circ} \mathrm{C}\right)\end{array}$ & $\begin{array}{c}\text { Maximum } \\
\text { temperature }\left({ }^{\circ} \mathrm{C}\right)\end{array}$ & $\begin{array}{c}\text { Minimum } \\
\text { temperature }\left({ }^{\circ} \mathrm{C}\right)\end{array}$ & $\begin{array}{c}\text { Rainfall } \\
(\mathrm{mm})\end{array}$ & $\begin{array}{c}\text { Geographic } \\
\text { location }\end{array}$ \\
\hline Lugo & Eurosiberian (Lucense) & 11.5 & 16.8 & 6.3 & 1084 & $43^{\circ} 0^{\prime} \mathrm{N}, 7^{\circ} 53^{\prime} \mathrm{W}$ \\
Santiago & Eurosiberian (Compostelano) & 13.4 & 18 & 8.8 & 1913 & $42^{\circ} 53^{\prime} \mathrm{N}, 8^{\circ} 32^{\prime} \mathrm{W}$ \\
Ourense & Mediterranean (Orensano) & 14.8 & 20.9 & 8.6 & 873 & $42^{\circ} 20^{\prime} \mathrm{N}, 7^{\circ} 52^{\prime} \mathrm{W}$ \\
Vigo & Eurosiberian (Miñense) & 14.1 & 18 & 10.2 & 1683 & $42^{\circ} 14^{\prime} \mathrm{N}, 8^{\circ} 44^{\prime} \mathrm{W}$ \\
\hline
\end{tabular}

the riparian forests, together with B. pubescens Ehrh. (= Betula alba L.) and Salix atrocinerea Brot. Birch pollen data comes from B. pubescens Ehrh., well represented in the whole territory and especially as a dominant species in the forests up to $700 \mathrm{~m}$ altitude in the Eurosiberian region. B. pendula Roth (= B. verrucosa Ehrh.) is also used as an ornamental tree, mainly in the city of Santiago. C. sativa L. is the main source of chestnut pollen captured in the pollen traps in the 4 cities, while C. crenata Siebold \& Zucc is frequently used as an ornamental in the area next to the pollen trap in Santiago.

\subsection{Study period}

Aerobiological and meteorological data from 1995 to 2009 (15 yr) in the cities of Santiago, Vigo and Ourense were utilised in the present survey, whereas for Lugo, data from the years 1999 to 2009 (11 yr) were used.

\subsection{Aerobiological monitoring}

Volumetric spore traps of the Hirst design (Hirst 1952) were used in all cities (make and model: LANZONI VPPS 2000). They were located at similar heights above ground (15 to $20 \mathrm{~m}$ ) in the Biology Faculty (South Campus) of the Santiago de Compostela University, in the City Hall building in Vigo, in the firefighters' building in Lugo and in the Sciences Faculty of the University of Vigo in Ourense.

Melinex tape coated with a $2 \%$ silicone solution was used as the pollen-trapping surface. The exposed tape was cut into 7 pieces, which were mounted on separate glass slides. Pollen grains were counted following the model proposed by the Spanish Aerobiological Network (R.E.A.), based on 4 longitudinal transects along the slides (Galán et al. 2007). The Alnus, Betula and Castanea pollen content in the air was expressed as the daily mean pollen concentration per cubic metre of air (no. of pollen grains $\mathrm{m}^{-3}$ ).

The period corresponding to each plant's APS (Jato et al. 2006) for each year and sampling station was determined using the method of Andersen (1991). The start date (APS onset) is the day on which the accumulated sum of pollen reaches $2.5 \%$ of the annual total, and the end date (APS end) is the day on which $97.5 \%$ of the annual total is reached. The APS is therefore considered as the period during which $95 \%$ of the annual total accumulated sum of pollen is recorded.

The date of the highest annual daily mean pollen concentration (peak date) was also considered. To determine the peak date, a 3-day running average of the daily mean pollen concentrations during all years was calculated.

\subsection{Thermal requirements}

\subsubsection{Chilling requirement}

To calculate the required chill accumulation we used:

(1) The method of Aron (1983), based on the chill hours accumulated between 0 and $7.2^{\circ} \mathrm{C}$ :

$$
\begin{aligned}
N= & 801+0.2523 \mathrm{~B}+7.57 \mathrm{~B}^{2} \times 10^{-4}-6.51 \mathrm{~B}^{4} \times 10^{-10} \\
& -11.44 T_{\mathrm{i}, \min }-3.32 \mathrm{~T}_{\mathrm{i}, \max }
\end{aligned}
$$

where $N=$ number of chill hours during the period considered; $\mathrm{B}=24 D\left(T_{\mathrm{h}}-T_{\min }\right) /\left(T_{\max }-T_{\min }\right)$, where $T_{\mathrm{h}}=$ threshold temperature and $D=$ length of the period (days); and $T_{i, \min }$ and $T_{\mathrm{i}, \max }=$ average of the daily minimum and maximum temperature, respectively, during the considered period.

(2) The Chuine \& Cour (1999) method, based on daily mean temperature:

$$
\begin{aligned}
& \mathrm{R}_{\mathrm{c}}\left(x_{\mathrm{t}}\right)=0, \text { if } x_{\mathrm{t}} \leq-3.04 \text { or } x_{\mathrm{t}} \geq 10.4 \\
& \mathrm{R}_{\mathrm{c}}\left(x_{\mathrm{t}}\right)=\left(x_{\mathrm{t}}+3.4\right) /\left(T_{\mathrm{h}}+3.4\right), \text { if }-3.04<x_{\mathrm{t}} \leq T_{\mathrm{h}} \\
& \mathrm{R}_{\mathrm{c}}\left(x_{\mathrm{t}}\right)=\left(x_{\mathrm{t}}-10.4\right) /\left(T_{\mathrm{h}}-10.4\right) \text {, if } T_{\mathrm{h}}<x_{\mathrm{t}} \leq 10.4
\end{aligned}
$$

where $T_{\mathrm{h}}=$ threshold temperature, $x_{\mathrm{t}}=$ daily mean temperature and $R_{c}$ is the chill requirement (dimensionless).

To calculate and quantify the most precise chilling requirement, a set of threshold temperatures from -2 to 
$11^{\circ} \mathrm{C}$ in steps of $0.25^{\circ} \mathrm{C}$ was assessed. The period of time during which the chill accumulation occurs was considered using 2 criteria. (1) Fixed start date for all years (1 November), and a range of completion dates (from 15 December to 31 January), increasing the calculations 1 in 1 day. (2) Variable dates depending on the temperatures recorded. The start date was the day on which the daily mean temperature equal to the chill threshold was registered. The completion date was the first day on which the daily mean temperature reached Tmin and started to follow a positive trend. This completion date coincides with the inflexion point of a polynomial second degree curve that followed temperatures from October of the preceding year to April of the same year as pollination.

\subsubsection{Heat requirement}

Different methods were also used to calculate the heat accumulation:

(1) The Rickman et al. (1983) method, which applies the following formula to the study period:

$$
{ }^{\circ} \mathrm{D}=\Sigma\left[\left(T_{\max }+T_{\min }\right) \times 0.5\right]-T_{\mathrm{h}}
$$

where ${ }^{\circ} \mathrm{D}=$ heat and $T_{\mathrm{h}}=$ the threshold temperature above which it is considered the plant accumulates heat.

(2) The Zalom et al. (1983) method, which uses daily maximum and minimum temperatures. The heat $\left({ }^{\circ} \mathrm{D}\right)$ is calculated according to the following premises:

$$
\begin{gathered}
{ }^{\circ} \mathrm{D}=0 \text {, if } T_{\mathrm{h}} \geq T_{\text {max }} \\
{ }^{\circ} \mathrm{D}=\left[\left(\left(T_{\max }-T_{\mathrm{h}}\right) / 2\right) /\left(\left(T_{\max }-T_{\mathrm{h}}\right) /\left(T_{\max }-T_{\min }\right)\right)\right], \\
\text { if } T_{\min }<T_{\mathrm{h}}<T_{\max } \\
{ }^{\circ} \mathrm{D}=T_{\text {med }}-T_{\mathrm{h}} \text {, if } T_{\mathrm{h}} \leq T_{\text {min }}
\end{gathered}
$$

where $T_{\text {med }}=$ daily mean temperature.

(3) The Chuine \& Cour (1999) method, which uses forcing units $\left(\mathrm{R}_{\mathrm{f}}\right)$ :

$$
\begin{gathered}
\mathrm{R}_{\mathrm{f}}\left(x_{\mathrm{t}}\right)=0 \text {, if } x_{\mathrm{t}} \leq 0 \\
\mathrm{R}_{\mathrm{f}}\left(x_{\mathrm{t}}\right)=28.4 /\left(1+\mathrm{e}^{-0.185\left(x_{\mathrm{t}}-18.4\right)}\right) \text {, if } x_{\mathrm{t}}>0
\end{gathered}
$$

where $x_{\mathrm{t}}=$ daily mean temperature and $\mathrm{R}_{\mathrm{f}}\left(\boldsymbol{x}_{\mathrm{t}}\right)=$ number of forcing units during the period considered.

(4) $T$ The ${ }^{\circ} \mathrm{D}=\Sigma T_{\max }$ method, which uses the sum of the daily maximum temperature values.

(5) The ${ }^{\circ} \mathrm{D}=\Sigma\left(T_{\max }-T_{\mathrm{h}}\right)$ method, which uses the difference between daily maximum temperature and threshold temperature.

(6) The Cesaraccio et al. (2004) method, in which heat accumulation was calculated in relation to the daily maximum and minimum temperatures as follows:

$$
\begin{aligned}
& \text { Ca }=T_{\text {med }}-T_{\mathrm{h}} \text {, if } 0 \geq T_{\mathrm{h}} \leq T_{\min } \leq T_{\text {max }} \\
& \mathrm{Ca}=\left(T_{\max }-T_{\mathrm{h}}\right)^{2} / 2\left(T_{\max }-T_{\text {min }}\right), \\
& \text { if } 0 \geq T_{\min } \leq T_{\mathrm{h}} \leq T_{\max } \\
& \mathrm{Ca}=0, \text { if } 0 \leq T_{\min } \leq T_{\max } \leq T_{\mathrm{h}} \\
& \mathrm{Ca}=0 \text {, if } T_{\text {min }}<0 \leq T_{\max } \leq T_{\mathrm{h}} \\
& \mathrm{Ca}=\left(T_{\max }-T_{\mathrm{h}}\right)^{2} / 2\left(T_{\max }-T_{\min }\right), \\
& \text { if } T_{\min }<0<T_{\mathrm{h}}<T_{\max }
\end{aligned}
$$

where $\mathrm{Ca}=$ number of heat requirement units.

The most accurate methods were selected according to the lower value of the coefficient of variation.

Calculations were made varying the temperature threshold $\left(T_{\mathrm{h}}\right)$ from 3 to $7.5^{\circ} \mathrm{C}$, in steps of $0.5^{\circ} \mathrm{C}$, in all cases. The time period over which heat was calculated was considered either (1) from a fixed date and without accumulated chilling: Alnus-December 15, Betula and Castanea-January 1, or (2) from the date following date following the completion of the chill requirement. Calculations were made using both the APS onset date and the peak date of each pollen type as the last date of heat accumulation.

\subsection{Weather-related parameters}

The meteorological data used (daily mean, maximum and minimum temperature and rainfall) were provided by the Spanish Meteorological Agency (AEMET) from weather stations located $<1 \mathrm{~km}$ from the spore traps from 1977 to 2009. From these data, a total of 121 variables in each city were calculated: (1) Monthly average daily temperatures (maximum, minimum and mean); (2) monthly sum of daily temperatures (maximum, minimum and mean), rainfall and number of rainy days from January to December; (3) seasonal averages for these parameters; and (4) annual and seasonal percentages of normal precipitation (PNP). PNP is the ratio of actual to normal precipitation for a given location and a given period, expressed as a percentage. PNP was expressed as a percentage of the long-term average for the period 1977 to 2007.

\subsection{Statistical treatment}

Linear regression models were developed in order to detect possible trends in major pollen behaviour characteristics over recent years. The SPSS 17.0 statistical software package was used. 


\section{RESULTS}

\subsection{Characterisation of APS}

The APS of the 3 pollen types studied at the 4 monitoring sites was characterised in terms of season start dates and end dates, duration and severity (i.e. total amount of pollen recorded annually) (Table 2). The evolution of the daily mean pollen concentrations during the APS are shown in Fig. 2.

The Alnus APS started on average 1 wk earlier in Ourense than in the other 3 cities, and ranged in duration from $49 \mathrm{~d}$ in Ourense to $60 \mathrm{~d}$ in Santiago. APS severity was greatest in Ourense, where both the annual total pollen and daily mean pollen counts were higher than in the other 3 cities (Table 2).

Table 2. Characteristics of the atmospheric pollen season (APS) calculated according to the 2.5\% method (Andersen 1991). Conc.: concentration

\begin{tabular}{|c|c|c|c|c|c|}
\hline & Onset date & End date & $\begin{array}{l}\text { Peak pollen conc. } \\
{\left[\mathrm{m}^{-3}\right] \text { (date) }}\end{array}$ & $\begin{array}{l}\text { Length in } \\
\text { days (year) }\end{array}$ & $\begin{array}{l}\text { Annual pollen severity } \\
\text { [total pollen] (year) }\end{array}$ \\
\hline \multicolumn{6}{|l|}{ Alnus } \\
\hline \multicolumn{6}{|l|}{ Santiago } \\
\hline Mean & 16 Jan & $18 \mathrm{Mar}$ & 80 & 60 & 455 \\
\hline Minimum & 20 Dec 2001 & 28 Feb 2001 & 12 (14 Feb 1996) & $38(2007)$ & 148 (2009) \\
\hline Maximum & 7 Feb 2007 & 29 Apr 1996 & 158 (10 Feb 1997) & 101 (1995) & 1170 (1997) \\
\hline \multicolumn{6}{|l|}{ Ourense } \\
\hline Mean & $1 \mathrm{Aug}$ & 25 Feb & 224 & 49 & 1784 \\
\hline Minimum & 20 Dec 2003 & 12 Feb 1997 & 72 (21 Jan 1998) & 34 (2008) & 645 (2001) \\
\hline Maximum & 20 Jan 2006 & 22 Mar 2000 & 534 (27 Jan 1997) & $70(2000)$ & $4526(2008)$ \\
\hline \multicolumn{6}{|l|}{ Vigo } \\
\hline Mean & 14 Jan & 5 Mar & 111 & 50 & 817 \\
\hline Minimum & 19 Dec 2001 & 19 Feb 2001 & 22 (16 Feb 1995) & 33 (2002 and 2008) & 158 (1995) \\
\hline Maximum & 26 Jan 2007 & 26 Mar 2007 & 245 (28 Jan 1997) & $62(1995)$ & $1718(2008)$ \\
\hline \multicolumn{6}{|l|}{ Lugo } \\
\hline Mean & 18 Feb & 7 Apr & 128 & 35 & 850 \\
\hline Minimum & 7 Jan 2004 & 24 Feb 2000 & 30 (17 Feb 2009) & 28 (1999) & 211 (2009) \\
\hline Maximum & 20 Dec 2001 & 21 Feb 2001 & 261 (29 Jan 2002) & $87(2004)$ & 1581 (1998) \\
\hline \multicolumn{6}{|l|}{ Betula } \\
\hline \multicolumn{6}{|l|}{ Santiago } \\
\hline Mean & 30 Mar & 11 May & 821 & 42 & 7105 \\
\hline Minimum & 16 Mar 2000 & 22 Apr 1997 & 171 (27 Mar 1998) & $20(2001)$ & 968 (1996) \\
\hline Maximum & 12 Apr 2006 & 17 Jun 1998 & 1833 (27 Apr 2004) & 90 (1998) & $15930(2002)$ \\
\hline \multicolumn{6}{|l|}{ Ourense } \\
\hline Mean & 27 Mar & 5 May & 253 & 39 & 1694 \\
\hline Minimum & 12 Mar 1997 & 16 Apr 1997 & 37 (27 Mar 1998) & $24(2007)$ & $236(2000)$ \\
\hline Maximum & 10 Apr 2007 & 23 May 2000 & 669 (27 Apr 2004) & $71(2000)$ & $4183(2009)$ \\
\hline \multicolumn{6}{|l|}{ Vigo } \\
\hline Mean & 26 Mar & 8 May & 216 & 29 & 1166 \\
\hline Minimum & 11 Mar 2000 & 21 Apr 1997 & 27 (18 Mar 2000) & $12(2003)$ & $157(1998)$ \\
\hline Maximum & 10 Apr 2006 & 23 May 1999 & 814 (28 Apr 2004) & $44(2004)$ & $2608(2004)$ \\
\hline \multicolumn{6}{|l|}{ Lugo } \\
\hline Mean & 4 Feb & 10 May & 219 & 28 & 1618 \\
\hline Minimum & 24 Mar 2009 & 1 May 2002 & 83 (22 Apr 2000) & 25 (2007) & 504 (1996) \\
\hline Maximum & 12 Apr 2007 & 21 May 2004 & 403 (22 Apr 2002) & $57(2000)$ & 3574 (1998) \\
\hline \multicolumn{6}{|l|}{ Castanea } \\
\hline \multicolumn{6}{|l|}{ Santiago } \\
\hline Mean & 17 Jun & 11 Aug & 90 & 55 & 841 \\
\hline Minimum & 31 May 1997 & $22 \mathrm{Jul} 2005$ & 16 (15 Jul 1996) & 34 (2005) & 258 (1996) \\
\hline Maximum & 25 Jun 1999 & 9 Jul 2009 & 174 (10 Jul 1999) & 84 (2009) & $1344(2000)$ \\
\hline \multicolumn{6}{|l|}{ Ourense } \\
\hline Mean & 15 Jun & $29 \mathrm{Jul}$ & 124 & 45 & 1105 \\
\hline Minimum & 3 Jun 1997 & $18 \mathrm{Jul} 2003$ & 45 (12 Jul 1998) & 33 (1999) & 450 (1998) \\
\hline Maximum & 22 Jun 2002 & 10 Aug 2007 & 318 (7 Jul 2005) & $61(2006)$ & 2349 (2008) \\
\hline \multicolumn{6}{|l|}{ Vigo } \\
\hline Mean & 9 Jun & 9 Aug & 93 & 60 & 763 \\
\hline Minimum & 25 May 1997 & 12 Jul 2003 & 22 (30 Jun 2004) & $24(2003)$ & $159(2004)$ \\
\hline Maximum & 24 Jun 2002 & 10 Sep 2007 & 206 (22 Jul 2008) & $96(2007)$ & $1655(2008)$ \\
\hline \multicolumn{6}{|l|}{ Lugo } \\
\hline Mean & 25 Jun & 8 May & 90 & 30 & 745 \\
\hline Minimum & 19 Jun 2003 & 24 Jul 2005 & 42 (3 Jul 2000) & 27 (1999) & $351(2007)$ \\
\hline Maximum & $1 \mathrm{Jul} 1999$ & 20 Aug 2003 & 192 (22 Jul 2008) & 62 (2003) & 1191 (2008) \\
\hline
\end{tabular}


The average start date of the Betula APS was almost identical in Ourense, Santiago and Vigo, while a delay of around a week was detected in Lugo. APS duration was very similar in the 4 cities (around $40 \mathrm{~d}$ ), while severity was greatest in Santiago, which displayed the highest daily mean pollen counts and the greatest total annual pollen count. The lowest values for both parameters were recorded in Vigo (Table 2).

Finally, the Castanea APS started 1 wk earlier in Vigo, and 1 wk later in Lugo, compared to Santiago and Ourense, where the APS started at roughly the same time (Fig. 2). APS duration was shorter in Lugo and Ourense than in Santiago and Vigo. APS severity was greater in Ourense and very similar in the other 3 cities (Table 2).
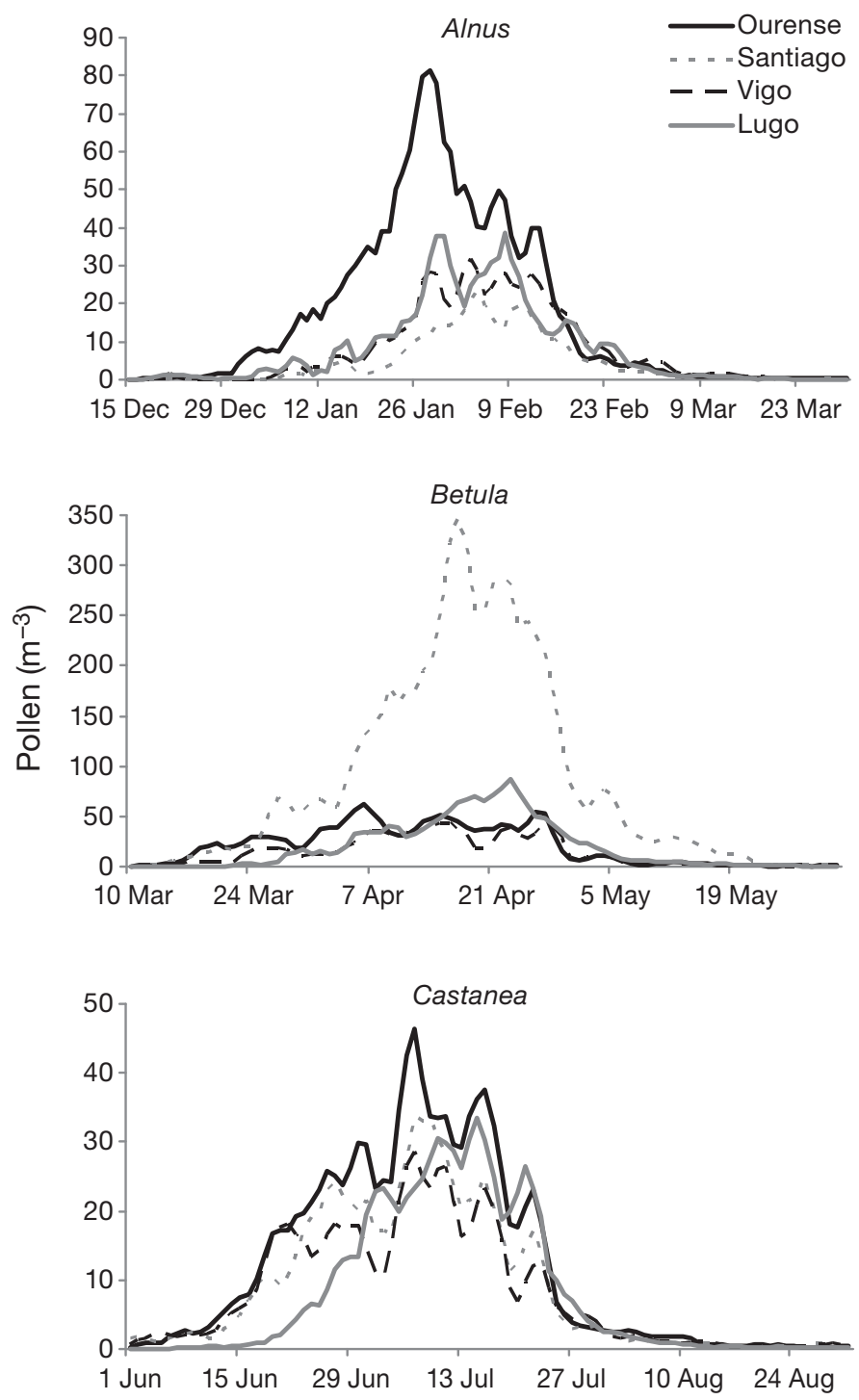

Fig. 2. Average of the daily mean pollen concentration for Alnus (upper panel), Betula (middle panel) and Castanea (lower panel) from 1995 to 2009 in Santiago, Vigo and Ourense and from 1999 to 2009 in Lugo

\subsection{APS trends}

\subsubsection{APS start date}

A slight trend towards a later start to the APS was observed in Alnus and Betula at all 4 sites. A similar delay was noted for peak date, although differences were not significant in any case. The Castanea APS start date remained generally constant at all sites over the study period. However, a tendency towards an earlier date was seen in Ourense and Lugo ( $p=$ not significant [ns]) when we only considered the years with the highest daily mean Castanea pollen counts.

\subsubsection{APS end date}

The only significant finding was a trend towards an earlier end to the Castanea pollen season in Ourense (adjusted $\mathrm{R}^{2}=0.275, \mathrm{p}<0.1$ ).

\subsubsection{Severity}

There was a trend towards a reduction in annual total Alnus pollen counts in Santiago and Lugo, and a trend towards increasing counts in Ourense and Vigo, though variations were not significant. A tendency towards increasing APS severity was observed for Betula at all sites (significant in Ourense: adjusted $\mathrm{R}^{2}=$ 0.411, p < 0.001) except Lugo. Finally, annual total Castanea pollen counts tended to increase in Ourense (adjusted $\left.\mathrm{R}^{2}=0.448, \mathrm{p}<0.001\right)$, Vigo $(\mathrm{p}<0.1)$ and Lugo $(\mathrm{p}=\mathrm{ns})$, but to decline slightly in Santiago $(\mathrm{p}=\mathrm{ns})$.

\subsection{Heat requirements}

\subsubsection{Chilling requirement}

Regardless of the dates and threshold temperatures applied, chilling units calculated using the Aron (1983) method displayed lower coefficients of variation than those obtained by the Chuine \& Cour (1999) method.

When the Aron (1983) method was applied using different threshold temperatures, the lowest coefficients of variation for the 4 cities were obtained with variable threshold temperatures and periods (Table 3). When the calculation was conducted using the same threshold temperature $\left(7.2^{\circ} \mathrm{C}\right)$, a previously established start date (1 November), and an end date between 15 December and 31 January (in daily steps), the lowest coefficient of variation was recorded for Vigo. With both methods, the highest number of chill units was recorded for Lugo and the 
Table 3. Chilling accumulation, measured with different versions of the Aron (1983) method, in the 4 cities. $T_{\mathrm{h}}$ : threshold temperature; CU: chilling units (dimensionless); Coeff. var: coefficient of variation

\begin{tabular}{|lcccc|}
\hline $\begin{array}{l}\text { Method/ } \\
\text { City }\end{array}$ & Date & $T_{\mathrm{h}}\left({ }^{\circ} \mathrm{C}\right)$ & $\mathrm{CU}$ & $\begin{array}{c}\text { Coeff. Var } \\
(\%)\end{array}$ \\
\hline Variable $\boldsymbol{T}_{\mathbf{h}}$ & & & & \\
Vigo & 30 Nov-24 Dec & 7.5 & 740 & 10.2 \\
Santiago & 24 Nov-30 Dec & 6.5 & 776 & 16 \\
Ourense & 5 Dec-29 Dec & 4.5 & 782 & 10.2 \\
Lugo & 8 Nov-31 Dec & 7.5 & 1096 & 7.2 \\
$\boldsymbol{T}_{\mathbf{h}}=\mathbf{7 . 2}{ }^{\circ} \mathbf{C}$ & & & & \\
Vigo & 1 Nov-19 Dec & 7.2 & 666 & 4.8 \\
Santiago & 1 Nov-15 Dec & 7.2 & 684 & 7.6 \\
Ourense & 1 Nov-15 Dec & 7.2 & 781 & 13.6 \\
Lugo & 1 Nov-13 Jan & 7.2 & 1035 & 7 \\
\hline
\end{tabular}

lowest for Vigo; the chilling period also ended later in Lugo than elsewhere.

\subsubsection{Heat requirement}

In most cases, the lowest coefficients of variation were achieved using the sum of daily maximum temperatures following the procedure outlined by Zalom et al. (1983). In order to compare heat requirements between sites and between species, the values obtained using the Zalom et al. (1983) method were selected, taking $6^{\circ} \mathrm{C}$ as the threshold temperature, the day following the completion of chilling requirement as the starting date for heat accumulation, and both APS onset and peak date as the end of heat requirement (Table 4). While Alnus in Ourense registered the lowest heat accumulation, Betula and Castanea registered the highest heat unit values in the same city.
For all 3 pollen types, the lowest coefficients of variation obtained by the different methods used to calculate heat accumulation were achieved when the sum of daily maximum temperatures method was applied (taking 16 December as the start date for heat accumulation and the date of APS onset as the end date) (Table 4). Using the Zalom et al. (1983) method, the lowest heat accumulation for Alnus and the highest for Betula and Castanea were recorded in Ourense. For all species, the lowest value for heat accumulation was recorded in Lugo, with the exception of the APS onset date for Alnus and Castanea.

For the 4 cities and all heat-calculation methods used, the lowest coefficients were obtained when the Castanea pollen-season start date was taken as the end date for heat accumulation. This species displayed the latest flowering period.

\subsection{Observed trends in heat requirement}

A trend towards an increase in accumulated chilling units was observed in Santiago (adjusted $\mathrm{R}^{2}=0.285$, $\mathrm{p}<0.05)$ and Ourense $(\mathrm{p}=\mathrm{ns})$; the reverse trend was observed in Vigo ( $\mathrm{p}=\mathrm{ns}$ ), while no trend was recorded in Lugo.

There was a slight trend towards increased accumulated heat (taking as start date both APS onset and peak date) in all pollen types and at all cities, though the trend was significant only for Castanea in Lugo $\left(\mathrm{R}^{2}=0.489, \mathrm{p}<0.05\right)$.

\subsection{Observed trends in weather-related parameters}

A tendency towards a decline in total annual rainfall was observed in all 4 cities (Table 5), though it was sig-

Table 4. Heat accumulated (dimensionless units) in the 4 cities calculated using the Zalom et al. (1983) method (using threshold temperature) and the sum of the daily maximum temperatures $\left(T_{\max }\right)$ method. APS: atmospheric pollen season, na: not applicable

\begin{tabular}{|c|c|c|c|c|c|c|c|}
\hline \multirow{2}{*}{$\begin{array}{l}\text { Method/ } \\
\text { City }\end{array}$} & \multirow{2}{*}{$\begin{array}{l}\text { Average onset } \\
\text { heat accumula- } \\
\text { tion date }\end{array}$} & \multirow[b]{2}{*}{$\begin{array}{l}\text { Alnus APS } \\
\text { onset date }\end{array}$} & \multirow[b]{2}{*}{$\begin{array}{l}\text { Alnus peak } \\
\text { APS date }\end{array}$} & \multirow{2}{*}{$\begin{array}{l}\text { Heat } \\
\text { Betula onset } \\
\text { APS date }\end{array}$} & \multirow{2}{*}{$\begin{array}{l}\text { Iccumulated - } \\
\text { Betula peak } \\
\text { APS date }\end{array}$} & \multirow[b]{2}{*}{$\begin{array}{c}\text { Castanea onset } \\
\text { APS date }\end{array}$} & \multirow[b]{2}{*}{$\begin{array}{l}\text { Castanea peak } \\
\text { APS date }\end{array}$} \\
\hline & & & & & & & \\
\hline \multicolumn{8}{|c|}{ Zalom et al. (1983) $\left(6^{\circ} \mathrm{C}\right.$ trend change $)$} \\
\hline Vigo & $25 \mathrm{Dec}$ & 111 & 238 & 535 & 644 & 1193 & 1479 \\
\hline Santiago & $31 \mathrm{Dec}$ & 121 & 204 & 548 & 667 & 1255 & 1434 \\
\hline Ourense & $30 \mathrm{Dec}$ & 87 & 188 & 617 & 722 & 1467 & 1784 \\
\hline Lugo & 1 Jan & 122 & 202 & 550 & 650 & 1248 & 1408 \\
\hline \multicolumn{8}{|c|}{$\Sigma T_{\max }$ (16 Dec start accumulation date) } \\
\hline Vigo & na & 406 & 741 & 1487 & 1731 & 2873 & 3390 \\
\hline Santiago & na & 420 & 645 & 1509 & 1807 & 3072 & 3402 \\
\hline Ourense & na & 295 & 568 & 1584 & 1835 & 3439 & 4034 \\
\hline Lugo & na & 331 & 527 & 1338 & 1582 & 2971 & 3302 \\
\hline
\end{tabular}


Table 5. Significant trend regression values observed with the weather-related parameters observed 1995-2009 and 1977$2007\left({ }^{*} \mathrm{p}<0.05,{ }^{* *} \mathrm{p}<0.01\right)$. Trends for Santiago in 1995-2009 were not significant; metereological data for Lugo in 19772007 were not available. T: temperature average, PNP: percentage of normal precipitation, Max: maximum

\begin{tabular}{|c|c|c|}
\hline Variable & Slope & Adjusted $\mathrm{R}^{2}$ \\
\hline \multicolumn{3}{|l|}{ 1995-2009 } \\
\hline \multicolumn{3}{|l|}{ Lugo } \\
\hline Max T Oct & 0.335 & $-0.414^{*}$ \\
\hline Rainfall summer & -12.82 & $0.429^{* *}$ \\
\hline PNP summer & -7.39 & $0.310^{* *}$ \\
\hline \multicolumn{3}{|l|}{ Ourense } \\
\hline Rainfall annual & -26.34 & $0.272^{* *}$ \\
\hline Summer & -12.86 & $0.141^{* *}$ \\
\hline PNP summer & -8.73 & $0.355^{* *}$ \\
\hline Max $T$ summer & 0.11 & $0.272^{* *}$ \\
\hline Sep & 0.294 & $0.398^{* *}$ \\
\hline \multicolumn{3}{|l|}{ Vigo } \\
\hline Min T Jun & 0.186 & $0.292^{* *}$ \\
\hline $\operatorname{Max} T$ Sep & 0.424 & $0.314^{* *}$ \\
\hline \multicolumn{3}{|l|}{$1977-2007$} \\
\hline \multicolumn{3}{|l|}{ Santiago } \\
\hline Mean $T$ annual & 0.104 & $0.719^{* *}$ \\
\hline Max $T$ Jan & 0.097 & $0.416^{* *}$ \\
\hline Feb & 0.111 & $0.299^{* *}$ \\
\hline Mar & 0.164 & $0.342^{* *}$ \\
\hline Apr & 0.116 & $0.168^{*}$ \\
\hline May & 0.167 & $0.431^{* *}$ \\
\hline Jun & 0.151 & $0.372^{* *}$ \\
\hline Jul & 0.076 & $0.143^{* *}$ \\
\hline Aug & 0.076 & $0.141^{* *}$ \\
\hline Oct & 0.078 & $0.136^{* *}$ \\
\hline Nov & 0.067 & $0.143^{* *}$ \\
\hline Dec & 0.086 & $0.314^{* *}$ \\
\hline PNP summer & 5.30 & $0.148^{* *}$ \\
\hline \multicolumn{3}{|l|}{ Ourense } \\
\hline Mean $T$ annual & 0.061 & $0.275^{* *}$ \\
\hline Max $T$ Jan & 0.074 & $0.218^{* *}$ \\
\hline Mar & 0.106 & $0.189^{*}$ \\
\hline Apr & 0.123 & $0.191^{*}$ \\
\hline May & 0.137 & $0.284^{* *}$ \\
\hline Jun & 0.134 & $0.286^{* *}$ \\
\hline Jul & 0.085 & $0.166^{* *}$ \\
\hline Aug & 0.106 & $0.267^{* *}$ \\
\hline Nov & 0.056 & $0.153^{* *}$ \\
\hline \multicolumn{3}{|l|}{ Vigo } \\
\hline Mean $T$ annual & 0.059 & $0.259^{* *}$ \\
\hline Max $T$ Jan & 0.102 & $0.400^{* *}$ \\
\hline Feb & 0.082 & $0.226^{* *}$ \\
\hline Mar & 0.105 & $0.196^{*}$ \\
\hline May & 0.098 & $0.188^{*}$ \\
\hline Dec & 0.072 & $0.205^{* *}$ \\
\hline Rainfall annual & -33.19 & $0.429^{* *}$ \\
\hline Rainfall winter & -17.48 & $0.251^{* *}$ \\
\hline Rainfall autum & -11.18 & $0.153^{*}$ \\
\hline PNP annual & -2.80 & $0.409^{* *}$ \\
\hline PNP spring & -2.10 & $0.177^{*}$ \\
\hline PNP autum & -4.22 & $0.190^{* *}$ \\
\hline
\end{tabular}

nificant only in Ourense (adjusted $\mathrm{R}^{2}=0.272, \mathrm{p}<0.05$ ), where there was also a decrease-albeit less significant $(\mathrm{p}<0.1)$-in annual PNP (expressed as a percentage of the long-term average for the period 1977 to 2007).

A non-significant trend of rising average temperatures, and particularly average daily maximum and minimum temperatures, was observed in Vigo. In Ourense, there was a slight falling trend both in average annual temperatures and in mean daily minimum temperatures, though the trend was not significant in either case. Similar trends were observed in Lugo and Santiago, with a slight decrease in mean daily maximum and minimum temperatures.

In order to determine the uniformity of these temperature trends over the year, a seasonal and monthly analysis of temperature parameters was performed from 1995 to 2009 (Table 5). Vigo displayed a non-significant trend towards increasing mean daily maximum and minimum temperatures in spring, and a rise in average maximum temperatures in summer; a significant rising trend was detected for daily maximum temperatures in September (adjusted $\mathrm{R}^{2}=0.424, \mathrm{p}<0.01$ ) and daily minimum temperatures in June (adjusted $\mathrm{R}^{2}=$ $0.186, \mathrm{p}<0.01$ ). Seasonal differences in Ourense included a significant increasing trend in mean daily maximum temperatures in the summer (adusted $\mathrm{R}^{2}=$ $0.272, \mathrm{p}<0.01$ ); a slight, non-significant decrease in mean maximum temperatures in winter and spring; and an increase in mean minimum temperatures in winter. Month-by-month analysis revealed only a significant increasing trend in mean daily maximum temperatures in September (adjusted $R^{2}=0.398, p<0.01$ ). The only significant trend in Lugo was an increase in mean daily maximum temperatures in October (adjusted $\mathrm{R}^{2}=0.414, \mathrm{p}<0.01$ ). No significant trends were observed for seasonal or monthly temperatures in Santiago.

Finally, a regression analysis was performed to chart recent trends in major weather-related variables in comparison to those observed for the same variables over the last 30 yr (1977 to 2007) in Santiago, Ourense and Vigo (Table 5). Weather data from Lugo for that period were not available. A significant rising trend was recorded for annual mean temperature in Santiago, Ourense and Vigo over the last 30 yr. Similar results were obtained for monthly maximum temperatures in most cases. Regarding the behaviour of rainfall variables, our results showed that the annual, winter and autumn total rainfall values present a negative significant trend over the last $30 \mathrm{yr}$ in Vigo. For the same period and parameters, no significant tendency was recorded in Santiago and Ourense. Finally, for PNP, there was similar trend to a significant reduction of the annual, spring, and autumn PNP in Vigo over the last 30 yr. In Santiago, a trend towards increasing summer PNP was noted for the same period. 


\section{DISCUSSION}

The APS for the 3 pollen types between displayed certain differences in the 4 cities, reflecting different local climate and phytogeographical characteristics.

The cooler winter usually recorded in Lugo, and the generally milder climate in Vigo, may account for the differences observed in APS onset. The Alnus APS started later in Lugo than in the other 3 cities (almost 1 mo later than Ourense, the first city to start the APS); the delay was less marked for Betula, which started its APS only $7 \mathrm{~d}$ later than in Vigo (the first area to start). The Castanea APS also started first in Vigo, beginning 16 d later in Lugo.

Climate-related differences may also account for differences in the chilling and heat requirements of the 3 species at different sites. The lower winter minimum temperatures in Lugo compared to the other 3 cities over the study period would explain the higher chilling accumulation recorded. The later start of the heat accumulation period would account for the observed delay in Alnus APS onset in Lugo and the less marked delay in Betula APS onset. Greater accumulation of chilling units in Lugo might also favour the reduction of the heat requirement for flowering in spring-flowering species. A lower number of heat units was required to reach peak date in Lugo for Alnus and Betula (both APS onset and peak date). The timing of flowering in spring-flowering tree species depends largely on a non-linear balance between the winter chilling required to break dormancy and the heat accumulated. The relationship between flowering onset and both chill and heat requirements has been reported by a number of authors who have found that chilling accumulation accelerates the renewal of growth once dormancy is broken; the more chilling units accumulated, the fewer forcing units are subsequently needed for budburst (Frenguelli \& Bricchi 1998, Jato et al. 2000, Rodríguez-Rajo et al. 2004, 2009). Several researchers also suggest that for Alnus, the shorter the period in which chilling requirement accumulated, the longer the required period of high temperatures (Rodríguez-Rajo et al. 2006, 2009). In areas where the tree needs to be protected from adverse meteorological conditions in order to preserve cells from frost damage, a delay in the phenological state of anthesis has been induced. Cooling is less important for plants that flower in late summer than for those that flower in early summer: inter-site differences observed in the Castanea pollen-season start date were less marked, and might be more attributable to phytogeographical differences or distance of the pollen sources from the trap, than to heat requirements.

The temperature trends recorded over recent decades within Europe display regional differences: some areas show little or no evidence of warming, while others display a trend towards higher temperatures. Therefore the influence of temperature trends on the APS of flowering trees is unlikely to be uniform. If the weather becomes warmer, earlier pollen seasons can be expected for early-flowering species, while late-flowering species will not experience significant phenological changes (Emberlin et al. 2002). Changes in the APS, due to earlier flowering or higher pollen production, are one reason for the impact of global warming on pollen-allergy sufferers (D'Amato et al. 2007); this accounts for the recorded year-on-year increase in the number of patients suffering allergies. The reported trend towards earlier pollen seasons varies in magnitude in different regions of Europe (Emberlin et al. 1993, 2002, García-Mozo et al. 2006, Frei \& Gassner 2008). Trends in APS severity also appear to vary (Emberlin et al. 2000, Frei \& Gassner 2008). Differences in APS duration of almost 1 mo have been noted for Quercus between different areas of Spain (García-Mozo et al. 2006). Using data from 1970 to 1990 , a clear tendency towards an earlier flowering phenophase was reported by Rial \& Díaz-Fierros (2009) for Castanea at various sites in Galicia. The same study also noted a non-significant trend towards earlier Betula flowering, and a non-uniform flowering pattern for Alnus. In the present study, observed trends, for both APS and weather-related parameters, for the 4 cities and 3 pollen types studied were by no means uniform. The trend towards increasing temperatures was more marked in the south of Galicia (Vigo and Ourense) than in more northern cities, which displayed greater variability. Differences were more marked in summer, and were more pronounced in the south, and particularly in Ourense. This is largely attributable to the local increase in maximum temperatures during September. Changes in weather trends observed in the final years of the present survey do not appear to be sufficient to prompt significant changes in the APS. The trend towards a slight delay in the start of Alnus and Betula pollen seasons may be due more to weather-related changes during the autumn-winter period than to changes during spring-summer. However, the significant trend towards an earlier APS end date for Castanea in Ourense may be due to the recorded increase in summer temperatures.

The temperature increase detected, especially during spring and summer, could account for the slight trend towards an earlier chestnut pollen season onset in all 4 cities, and for the advance of the Castanea pollen season end date observed in Ourense (the only city where the increase in summer maximum temperatures was significant). An increase in the annual temperature of $0.18^{\circ} \mathrm{C}$ every $10 \mathrm{yr}$ has been reported for the period 1960 to 2006 in Galicia, the increase proving more marked from 1972 (Cruz et al. 2009). The same 
study found that the most pronounced change was for maximum temperatures, mainly in spring and summer. These findings are very similar to those in the present study for the period 1995 to 2009. Here, the average annual temperature displayed an increasing trend in Vigo, Santiago and Ourense. However, seasonal or monthly changes were more evident in some cities: maximum temperatures in September or October displayed an increasing trend at Ourense, Vigo and Lugo, while summer temperatures showed significant increases in Ourense. These more uniform changes detected during the autumn months in the south and inland area of Galicia could influence the chilling accumulation period and consequently prompt a change in the onset of the pollen season. It is worth noting that the significant increase observed for the autumn months during the 1995-2009 period was not detected when analysis covered a longer period (1977 to 2007); the increase in temperature observed during the summer months in Ourense was more pronounced in the 1995-2009 period.

The non-uniform trends in weather conditions over the year at the 4 sites studied may account for the slight changes observed in APS start and end dates, since plants adapt their phenological behaviour to these environmental variations.

Acknowledgements. This study was subsidised by the Consellería de Medio Ambiente e Desenvolvemento Sostible and Consellería de Sanidade of the Xunta de Galicia.

\section{LITERATURE CITED}

Andersen TB (1991) A model to predict the beginning of the pollen season. Grana 30:269-275

Aron R (1983) Availability of chilling temperatures in California. Agric Meteorol 28:351-363

Belmonte J, Roure JM, March X (1998) Aerobiology of Vigo, north-western Spain: atmospheric pollen spectrum and annual dynamics of the most important taxa and their clinical importance for allergy. Aerobiologia 14:155-163

Cesaraccio C, Spano D, Snyder RL, Duce P (2004) Chilling and forcing model to predict bud-burst of crop and forest species. Agric For Meteorol 126:1-13

Chuine I, Cour P (1999) Climatic determinants of budburst seasonality in four temperate-zone tree species. New Phytol 143:339-349

Cruz R, Lago A, Lage A, Rial ME, Díaz-Fierros F, Salsón S (2009) Evolución reciente del clima de Galicia. Tendencias observadas en las variables meteorológicas. In: Xunta de Galicia (ed) Evidencias e impactos del cambio climático en Galicia. Consellería de Medio Ambiente, Santiago de Compostela, p 19-58

> D'Amato G, Cecchi L, Bonini S, Nunes C and others (2007) Allergenic pollen and pollen allergy in Europe. Allergy 62:976-990

del Rio S (2005) El cambio climático y su influencia en la vegetación de Castilla y León (España). In: Rivas Martínez S (ed) Itinera geobotanica, Vol 16. University of León, León
Emberlin J, Savage J, Jones S (1993) Annual variations in grass pollen seasons in London, 1961-1990: trends and forecast models. Clin Exp Allergy 23:911-918

Emberlin J, Jäeger S, Dominguez E, Galán C and others (2000) Temporal and geographical variations in grass pollen seasons in areas of western Europe: an analysis of season dates at sites of the European pollen information system. Aerobiologia 16:373-379

Emberlin J, Detandt M, Gehrig R, Jaeger S, Nolard N, RantioLehtimaki A (2002) Responses in the start of Betula (birch) pollen season to recent changes in spring temperatures across Europe. Int J Biometeorol 46:159-170

Frei T, Gassner E (2008) Climate change and its impact on birch pollen quantities and the start of the pollen season, an example from Switzerland for the period 1969-2006. Int J Biometeorol 52:667-674

Frenguelli G, Bricchi E (1998) The use of the pheno-climatic model for forecasting the pollination of some arboreal taxa. Aerobiologia 14:39-44

Galán C, Cariñanos P, Alcázar P, Domínguez-Vilches E (2007) Spanish Aerobiological Network: management and quality control. Servicio de Publicaciones, University of Córdoba, Córdoba, Spain

García-Mozo H, Galán C, Jato V, Belmonte J and others (2006) Quercus pollen season dynamics in the Iberian peninsula: response to meteorological parameters and possible consequences of climate change. Ann Agric Environ Med 13:209-224

> Hirst JM (1952) An automatic volumetric spore trap. Ann Appl Biol 39:257-265

Ickovic M, Thibaudon M (1991) Allergenic significance of Fagaceae pollen. In: D'Amato G, Spieksma FT, Bonini S (eds) Allergenic pollen and pollinosis in Europe. Blackwell Scientific, Oxford

IPCC (Intergovernmental Panel on Climate Change) (2007) Climate change 2007. The physical science basis. Contribution of Working Group I to the Fourth Assessment Report of the Intergovernmental Panel on Climate Change. Cambridge University Press, Cambridge

Jato V, Frenguelli G, Rodríguez-Rajo FJ, Aira MJ (2000) Temperature requirements of Alnus pollen in Spain and Italy (1994-1998). Grana 39:240-245

Jato V, Rodríguez-Rajo FJ, Alcázar P, De Nuntiis P, Galán C, Mandrioli P (2006) May the definition of pollen season influence aerobiological results? Aerobiologia 22:13-25

Jato V, Rodríguez-Rajo FJ, Aira MJ (2007) Use of phenological and pollen-production data for interpreting atmospheric birch pollen curves. Ann Agric Environ Med 14:271-280

Jato V, Rodríguez-Rajo FJ, Seijo MC, Aira MJ (2009) Poaceae pollen in Galicia (N.W. Spain): characterisation and recent trends in atmospheric pollen season. Int J Biometeorol 53: 333-344

Meehl GA, Stocker TF, Collins WD, Friedlingstein P and others (2007) Global climate projections. In: Climate change 2007. The physical science basis. Contribution of Working Group I to the Fourth Assessment Report of the Intergovernmental Panel on Climate Change. Cambridge University Press, Cambridge

Recio M, Rodríguez-Rajo FJ, Jato MV, Trigo MM, Cabezudo B (2009) The effect of recent climatic trends on Urticaceae pollination in two bioclimatically different areas in the Iberian Peninsula: Malaga and Vigo. Clim Change 97: 215-228

Rial ME, Díaz-Fierros F (2009) Influencia del cambio climático en las fenofases de diferentes especies vegetales y animales y el riesgo de heladas. In: Xunta de Galicia (ed) Evidencias e impactos del cambio climático en Galicia. Con- 
sellería de Medio Ambiente, Santiago de Compostela, p 91-109

Rickman RW, Klepper BL, Peterson CM (1983) Time distributions for describing appearance of specific culms of winter wheat. Agron J 75:551-556

Rivas-Martinez S, Rivas-Saenz S (2010) Worldwide bioclimatic classification system, 1996-2009. Phytosociological Research Center, Madrid. Available at: www. globalbioclimatics.org

Rodríguez-Rajo FJ, Dopazo A, Jato V (2004) Environmental factors affecting the start of the pollen season and concentrations of airborne Alnus pollen in two localities of Galicia (NW Spain). Ann Agric Environ Med 11:35-44

Submitted: June 8, 2010; Accepted: October 23, 2010
Rodríguez-Rajo FJ, Fernández-González D, Vega-Maray A, Suárez FJ, Valencia RM, Jato V (2006) Biometeorological characterization of the winter in the NW Spain based on Alnus flowering requirements. Grana 45:288-296

Rodríguez-Rajo FJ, Grewling L, Stach A, Smith M (2009) Factors involved in the phenological mechanism of Alnus flowering in central Europe. Ann Agric Environ Med 16:277-284

Zalom FG, Goodell PB, Wilson LT, Barnet WW, Bentley WJ (1983) Degree-days: the calculation and use of heat units in pest management. Leaflet 21373. University of California Division of Agriculture and Natural Resources, Davis, CA

Proofs received from author(s): July 28, 2011 